\author{
MARIA JOLANTA RĘDOWICZ \\ Pracownia Molekularnych Podstaw Ruchów Komórkowych \\ Zakład Biochemii \\ Instytut Biologii Doświadczalnej im. M. Nenckiego PAN \\ Pasteura 3, 02-093 Warszawa \\ E-mail: j.redowicz@nencki.gov.pl
}

\title{
MODYFIKACJE POTRANSLACYJNE AKTYNY
}

\section{WPROWADZENIE}

Aktyna to jedno $z$ białek najobficiej występujących u eukariontów, stanowi bowiem 10-20\% całkowitej ilości białka, w zależności od typu komórki. Choć wykryta początkowo w mięśniu szkieletowym, występuje we wszystkich komórkach eukariotycznych, od pierwotniaków i grzybów, po rośliny i kręgowce, stanowiąc integralna część cytoszkieletu (POLLARD i COOPER 2009, BLANCHOIN i współaut. 2014). Homologi aktyny wykryto również w bakteriach (SHAEVITZ i GiTAI 2010). U ludzi aktyna jest kodowana przez sześć genów:

- ACTA1, kodujący izoformę a występująca w mięśniu poprzecznie prażkowanym;

- ACTA2 i ACTA3 (ACTG2) kodujace, odpowiednio, izoformy a i $\gamma$ występujace $w$ mięśniach gładkich, przy czym ACTA3 występuje w mięśniówce gładkiej układu pokarmowego;

- ACTC1, kodujacy izoformę a występującą w mięśniu sercowym;

- ACTB i ACTG1 kodujace tzw. cytoplazmatyczne aktyny, odpowiednio $\beta$ i $\gamma$ (VANDEKERCKHOVE i WEBER 1978, HERMAN 1993, PERRIN i ERVASTI 2010).

Masa czasteczkowa wszystkich znanych izoform aktyny wynosi około 42,3 kDa; składa się na nia, w zależności od izoformy i pochodzenia białka, od 375 do 377 reszt aminokwasowych. Zarówno sekwencje genów, jak i kodowanych przez nie izoform aktyny sa wysoce zachowane $\mathrm{w}$ toku ewolucji i wykazuja około 90\% identyczności pomiędzy poszczególnymi białkami (VANDEKERCKHOVE i Weber 1978, Herman 1993, PERrin i ERVA-
STI 2010). Także struktura trzeciorzędowa wszystkich znanych aktyn jest bardzo zbliżona. Dzięki poznaniu struktury krystalicznej tego globularnego białka, w aktynie wyróżniono 4 subdomeny, które są zaangażowane bądź w oddziaływania niekowalencyjne pomiędzy monomerami $\mathrm{w}$ tworzonym przez aktynę filamencie (monomery $\mathrm{w}$ filamencie zwane sa protomerami), bądź $\mathrm{w}$ oddziaływania $z$ innymi białkami, determinujacymi stan organizacji aktyny (Ryc. 1A). W szczelinie (zwanej również katalityczna) pomiędzy subdomenami, znajdują się miejsca wiazania kationów dwuwartościowych i nukleotydów. Ich zwiazanie oraz zdolność do hydrolizy ATP do ADP i ortofosforanu $\left(\mathrm{P}_{\mathrm{j}}\right)$ sa niezbędne dla utrzymania prawidłowej konformacji aktyny, a więc i funkcji białka (OTTERBEIN i współaut. 2001). Aktyna występuje w dwóch zasadniczych formach: monomerycznej (globularnej, G-aktyna) i filamentowej (F-aktyna) (Ryc. 1A i B), a przejście pomiędzy obiema formami jest procesem niezwykle dynamicznym i ściśle regulowanym w komórce przez liczne białka wiażące aktynę (ang. actin-binding proteins) (ODA i współaut. 2009, POLLARD i COOPER 2009, BLANCHOIN i współaut. 2014). Grubość filamentów tworzonych przez aktynę wynosi ok. $7 \mathrm{~nm}$, a ich długość może osiagać nawet kilka $\mu \mathrm{m}$. Tworza one podwójna prawoskretna helisę o skręcie około $166^{\circ}$, w której każdy protomer oddziałuje siłami niekowalencyjnymi $z$ czterema sasiednimi. Podstawowa jednostką filamentu, o długości około $37 \mathrm{~nm}$, jest para siedmiu protomerów przypadających na jeden skręt helisy (Ryc. 1B). 

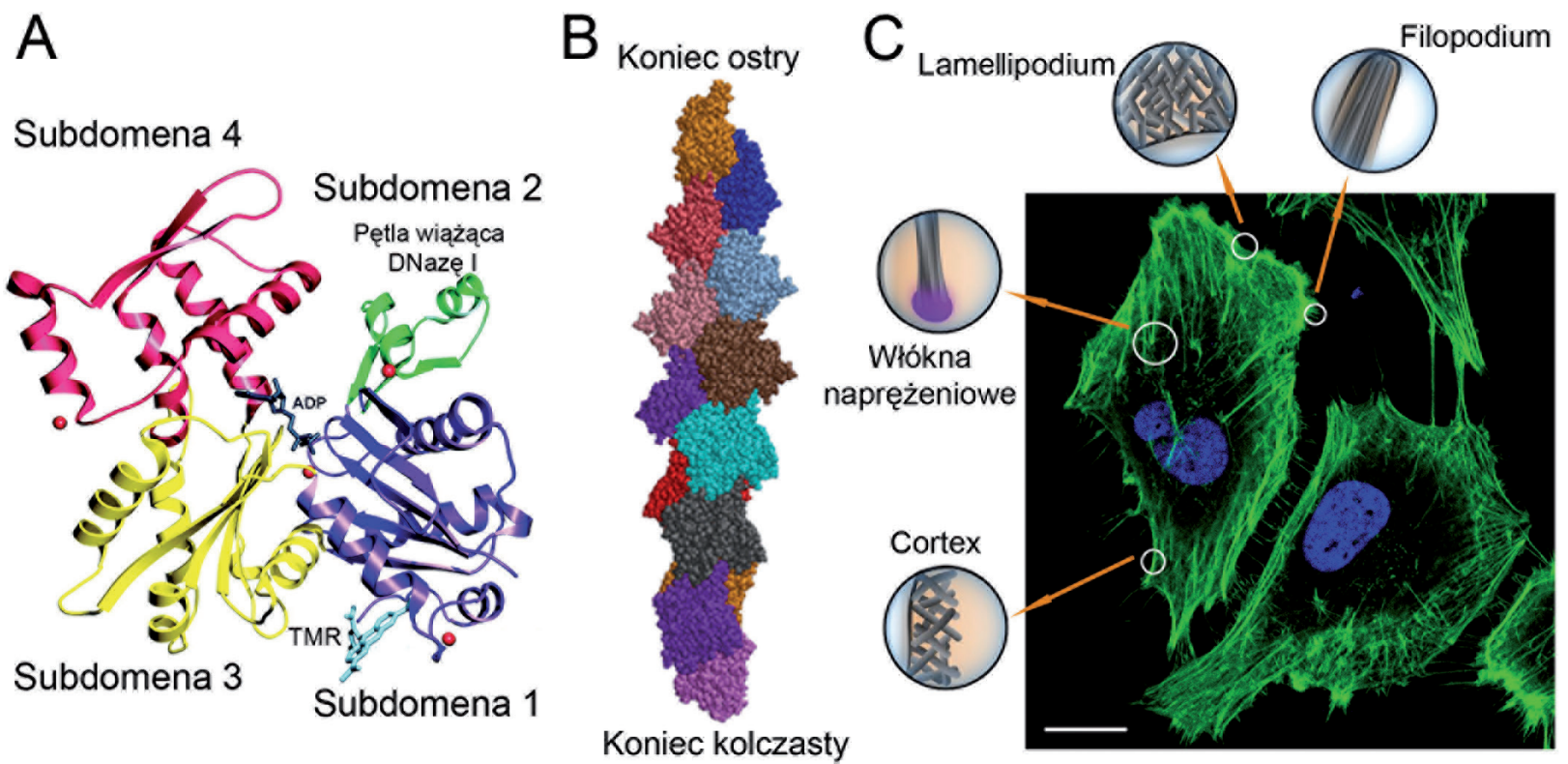

Ryc. 1. Budowa i organizacja aktyny w komórce.

A - Schemat struktury krystalicznej monomeru aktyny ze zwiazanym ADP w kieszeni katalitycznej. Subdomeny sa wyróżnione następującymi kolorami: pierwsza - fiolet; druga - zielony; trzecia - żółty i czwarta - czerwony. Czerwone kulki, jony $\mathrm{Ca}^{2+}$ zwiazane przez monomer aktyny w subdomenach 1, 2 i 4 oraz w kieszeni katalitycznej obok zwiazanego nukleotydu. TMR, (tetrametylorodamino-5-maleimid) przyłaczony kowalencyjnie do reszty Cys-374 w celu zapobieżenia polimeryzacji uniemożliwiajacej otrzymanie kryształu aktyny. Struktura zdeponowana w bazie PDBj jako 1J6Z przez OTTERBEIN i współaut.(2001). B - Schemat budowy filamentu aktynowego w oparciu o strukturę krystaliczna monomeru. Poszczególne monomery w filamencie (protomery) zaznaczone sa różnymi kolorami. Schemat przedstawia podstawowa jednostkę filamentu. C - Organizacja filamentów aktynowych (wyznakowanych znacznikiem fluorescencyjnym Alexa488 skoniugowanym $z$ faloidyna, mikotosyna specyficznie wiażaca się $z$ filamentami aktyny) w migrującej komórce glioblastoma U251-MG. Schematy przedstawiają organizację filamentów w zaznaczonych rejonach komórki. Kolorem fioletowym oznaczono miejsce przyczepu włókien naprężeniowych w strukturach adhezyjnych. Jądro komórkowe wybarwiono znacznikiem fluorescencyjnym DAPI (kolor niebieski). Przekrój komórki (o grubości $0,5 \mu \mathrm{m})$ uzyskano $\mathrm{w}$ konfokalnym mikroskopie fluorescencyjnym przez mgr Olenę Karatsai, doktorantkę w pracowni kierowanej przez autorkę artykułu. Skala, $20 \mu \mathrm{m}$. Rycinę przygotowano w oparciu o adaptację ilustracji zawartych w artykułach: A, OTTERBEIN i współaut. (2001); B, ODA i współaut. (2009) i C, BLANCHOIN i współaut. (2014)

Podobnie jak mikrotubule, filamenty aktynowe sa spolaryzowane, tzn. maja nierównocenne końce (patrz KŁOPOCKA oraz JAWORSKI w tym zeszycie KOSMOSU). Wyróżnia się (i) koniec ostry (ang. pointed-end), w którym protomery zawieraja ADP, do którego kolejne monomery ATP-aktyny przyłaczaja się wolno, stąd zwany jest on również końcem wolno rosnącym lub końcem minus oraz (ii) koniec kolczasty (ang. barbed-end), zwany także końcem brodatym, w którym protomery zawieraja ATP, do którego kolejne monomery ATP-aktyny przyłączaja się szybko, stąd jego nazwa koniec szybko rosnacy lub koniec plus (Ryc. 1B). W komórce końce kolczaste filamentów znajduja się $z$ reguly $w$ pobliżu błony komórkowej oraz błon organelli i peccherzyków lipidowych (ODA i współaut. 2009, POLLARD i COOPEr 2009, BLANCHOIN i współaut. 2014).

Filamenty aktynowe nie tylko pełnia funkcję podporowa i swoistego łącznika po- między błona komórkowa a wnętrzem komórki (jest to możliwe dzięki bezpośredniemu lub pośredniemu oddziaływaniu aktyny $z$ białkami błonowymi), ale wspólnie $z$ miozyna biora również udział w aktywności kurczliwej komórek (w tym mięśni). Filamenty aktynowe stanowią również tory, po których, przy udziale miozyn niekonwencjonalnych (POLLARD i COOPER 2009; patrz SUSZEK i współaut. w tym zeszycie KOSMOSU), przenoszone sa ładunki (cargo), którymi moga być pęcherzyki, organelle i kompleksy białkowe. Wykazano także obecność aktyny w jądrze komórkowym i jej zaangażowanie $\mathrm{w}$ regulacji transkrypcji i transporcie $\mathrm{w}$ nukleoplazmie (BELIN i MUlLINS 2013; patrz NOWAK i REDOWICZ w tym zeszycie KOSMOSU). Filamenty tworzone przez aktyne $\mathrm{w}$ mięśniu wraz ze zwiazanymi $z$ nia białkami noszą nazwę filamentów cienkich; ich odpowiednikiem w komórkach niemięśniowych sa mikrofilamenty. Mikrofilamenty tworza supramolekularne 

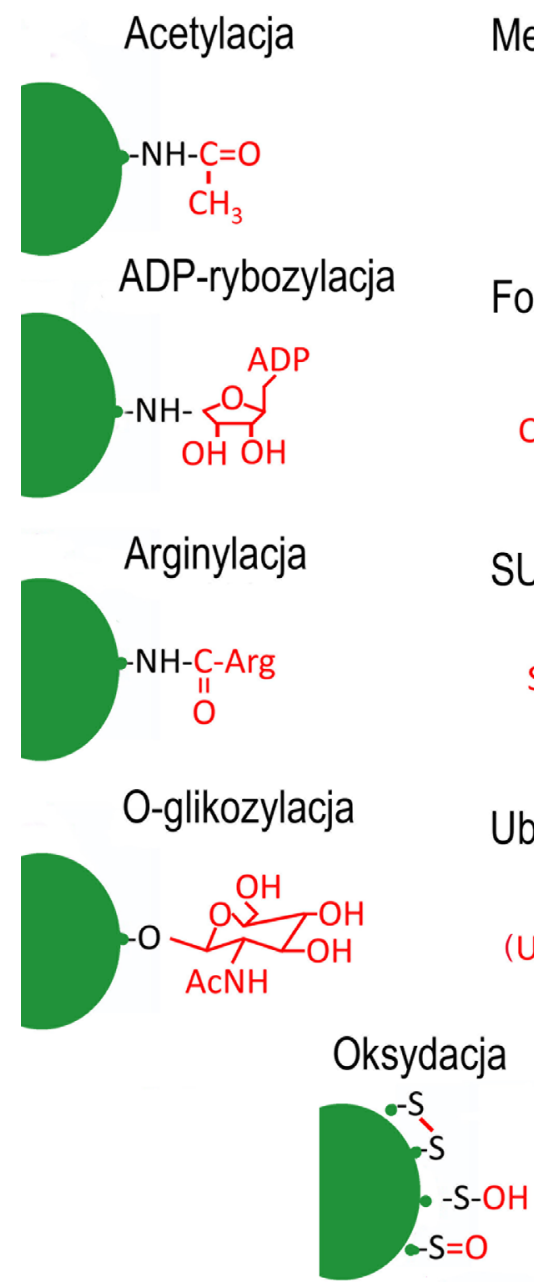

Ryc. 2. Schemat reakcji modyfikujacych reszty aminokwasowe aktyny (na zielono).

Wzory/skróty przyłączonych związków/białek oraz możliwe modyfikacje typu redox grup tiolowych zaznaczono kolorem czerwonym. Schemat inspirowany rycina $\mathrm{w}$ artykule przeglądowym TERMAN I KASHINA (2013).

struktury, takie jak sieci aktynowe występujące głównie w krawędzi wiodącej migrującej komórki (lamellipodium) i pod błoną komórkową (ang. cortex), wiązki filamentów (ang. actin bundles) obecne głównie w filopodiach oraz włóknach naprężeniowych (ang. stress fibers), niezbędnych dla generacji siły umożliwiajacej translokację komórki (Ryc. 1C) (BlANCHOIN i współaut. 2014). Powstawanie tych złożonych struktur jest możliwe dzięki precyzyjnie regulowanemu i dynamicznemu oddziaływaniu mikrofilamentów $z$ cała plejada białek wiążacych filamenty aktynowe (POLlARD i COOPER 2009). Funkcje aktyny w komórce są również modulowane/regulowane przez modyfikacje potranslacyjne, którym ulega to białko (TERMAN i KASHINA 2013). Wpływowi tych najczęściej odwracalnych modyfikacji kowalencyjnych na funkcje aktyny poświęcony jest niniejszy artykuł.

\section{ACETYLACJA}

Acetylacja białek to proces przyłaczania reszty acetylowej, pochodzacej $z$ acetylo-CoA, do białka w miejsce aktywnego atomu wodoru w bocznej grupie funkcyjnej (najczęściej aminowej) reszty aminokwasowej białka (Ryc. 2). Najczęściej acetylacji ulegają reszty lizynowe, ale inne reszty również moga być acetylowane.

Pierwsze informacje o acetylacji aktyny pochodza $z$ końca lat 70 . XX w., kiedy to podczas sekwencjonowania aktyn cytoplazmatycznych poprzez hydrolizę aminokwasów zaobserwowano, że na końcu aminowym znajduje się reszta acetylowa, zamiast spodziewanej metioniny (VANDEKERCKHOVE i WeBER 1978). Obecnie wiadomo, że poza Met-1 i Glu-2, acetylowanych może być osiem innych reszt aminokwasowych (Tabela 1). Acetylację aktyny katalizuja acetylotransferazy, które w przypadku acetylacji reszt na końcu aminowym sa wspomagane przez aminopeptydazy, które odcinaja Met1. Natomiast proces odwrotny katalizuja deacetylazy, przy czym nie sa to enzymy specyficzne dla aktyny. I tak np. deacetylacja aktyny przez deacetylaze histonu HDAC6 prowadzi do przebudowy cytoszkieletu aktynowego, zaś acetylacja aktyny obecnej w jadrze komórkowym przez acetylotransferaze histonu reguluje udział aktyny $\mathrm{w}$ procesie transkrypcji (Kovacs i współaut. 2004, MOTTET i CASTRONOVO 2008, STARHEIM i współaut. 2012, TERMAN i KASHINA 2013). U zdecydowanej większości gatunków acetylacja na końcu aminowym jest niezbędna dla zachowania struktury i funkcji aktyny (TERMAN i KASHINA 2013). W przypadku izoform mięśniowych zaobserwowano, że acetylacja przyspiesza oddziaływanie aktyny $z$ miozyna oraz może warunkować ubikwitynację aktyny, determinując dalsze losy białka w komórce (TERMAN i KASHINA 2013). Natomiast w przypadku organizmów niższych, wpływ tej modyfikacji jest zróżnicowany. Dla przykładu, u Drosophila melanogaster nie dochodzi do acetylacji jednej $z$ izoform aktyny mięśniowej (ACT88F) (SCHMITZ i współaut. 2000), a u drożdży Saccharomyces cerevisiae acetylacja wprawdzie zachodzi, ale nie jest niezbędna dla funkcjonowania aktyny (COOK i współaut. 1991).

\section{ADP-RYBOZYLACJA}

ADP-rybozylacja to przyłaczenie reszty ADP-rybozylowej $z$ dinukleotydu nikotyno-amidoadeninowego do reszt aminokwasowych białka; najczęściej modyfikowana jest reszta arginylowa (Tabela 1, Ryc. 2). Proces ten katalizuja ADP-rybozylotransferazy, syn- 
Tabela 1. Modyfikacje potranslacyjne aktyny.*

\begin{tabular}{ll}
\hline Modyfikacja & Zidentyfikowane modyfikowane reszty aminokwasowe \\
\hline Acetylacja & Met -1, Asp/Glu-2, Asp-3, Lys-50, Lys-61, Lys-68, Lys-191, Lys-326, Lys-328 \\
\hline ADP-rybozylacja & Arg-28, Arg-95, Thr-148, Arg-177, Arg-206, Arg-372 \\
\hline Arginylacja & Asp-3, Ser-52, Ile-87, Phe-90, Gly-152, Leu-295, Asn-299 \\
\hline & Ser-14, Ser-33, Ser-52, Tyr-53, Ser-60, Thr-66, Tyr-69, Thr-89, Tyr-91, Thr-148, Thr-160, \\
Fosforylacja & Thr-162, Tyr-166, Tyr-169, Thr-186, Tyr-188, Tyr-198, Ser-199, Thr/Ser-201, Thr-202, \\
& Thr-203, Tyr-218, Thr-229, Ser-233, Ser-239, Tyr-240, Thr-262, Tyr-294, Thr-297, Tyr- \\
\hline Glutationylacja & Cys-217, Cys-374 \\
\hline O-Glikozylacja & Ser-52, Ser-155, Ser-199, Ser-232, Ser-323, Ser-368 \\
\hline Isoaspartylacja & Asp-25, Asp-179 \\
\hline Karbonylacja & His-40, His-87, His-173, Cys-374 \\
\hline Malonylacja & Lys-61 \\
\hline Metylacja & His-73, Ile-87, Asn-299, Lys-326 \\
\hline Nitracja & Tyr-53, Tyr-69, Tyr-91, Tyr-198, Tyr-218, Tyr-240, Tyr-294, Tyr-362 \\
\hline Nitrozylacja & Cys-217, Cys-257, Cys-285, Cys-374 \\
\hline Oksydacja & Met-44, Met-47, Trp-79, Met-82, Trp-86, Met-178, Met-190, Cys-217, Met-227, Cys-257, \\
\hline Sieciowanie & Met-269, Cys-272, Cys-285, Met-325, Trp-340, Met-355, Trp-356, Cys-374 \\
\hline SUMO-ilacja & Lys-68, Lys-284 \\
\hline Transglutaminacja & Gln-41 \\
\hline Ubikwitynacja & Lys-50, Lys-61, Lys-68, Lys-84, Lys-113, Lys-118, Lys-191, Lys-291, Lys-315, Lys-326, \\
\hline & Lys-328 \\
\hline
\end{tabular}

*Modyfikacje reszt oznaczonych pogrubiona czcionka maja znaczenie dla funkcji aktyny.

tetyzowane przez patogeny bakteryjne i eukariotyczne, aczkolwiek obecność tych transferaz stwierdzono w szeregu tkanek i komórek prawidłowych, np. w mózgu i mięśniach oraz w płytkach krwi (OKAZAKI i Moss 1996). W przypadku ADP-rybozylotransferazy patogenów, najlepiej poznana jest toksyna C2 laseczki jadu kiełbasianego (Clostridium botulinum), która ADP-rybozyluje resztę Arg-177 (zlokalizowana w subdomenie 3) w monomerach aktyn cytoplazmatycznych. Powoduje to zahamowanie polimeryzacji aktyny, co prowadzi do dezorganizacji sieci aktynowej i do zaokraglania się komórek, a w konsekwencji do ich smierci. Jest to jeden z mechanizmów zwiazanych $z$ toksycznościa jadu kiełbasianego (MONTECUCCO i RASOTTO 2015). Zaobserwowano również, że modyfikowana aktyna blokuje polimeryzację niemodyfikowanego białka poprzez przyłączanie się (przykrywanie, ang. capping) do końca szybko rosnacego niemodyfikowanej aktyny. Ponadto, ADP-rybozylacja reszty Arg-177 wpływa na aktywność ATPazowa aktyny i jej oddziaływanie $z$ żelsolina, białkiem wpływajacym m.in. na zdolność inicjacji aktyny do tworzenia filamentów, czyli na proces nukleacji filamentów. $Z$ kolei modyfikacja reszty Thr-148 przez ADP-rybozylotransferaze TccC3 $z$ Photorhabdus luminescens, śmiertelnego patogenu owadów, powoduje zwiększenie puli F-aktyny.

Wpływ ADP-rybozylacji katalizowanej przez enzymy syntetyzowane w komórkach eukariotycznych zależy od rodzaju toksyny i miejsca modyfikacji. ADP-rybozylotransferaza A otrzymana $z$ erytrocytów indyka, modyfikujaca reszty Arg-95 i Arg-372 (obie zlokalizowane w subdomenie 1), wpływa jedynie na proces nukleacji filamentów i w konsekwencji spowalnia proces polimeryzacji (JUST i współaut. 1995). Natomiast ADP-rybozylotransferaza $Z$ granulocytów kurczaka, modyfikujacca reszty Arg-28 i Arg-206, blokuje polimeryzacje i wiąanie przez aktynę DNazy I, przy czym to modyfikacja reszty Arg-206 (zlokalizowanej w subdomenie 4 cząsteczki aktyny) wydaje się wywierać negatywne skutki. Może to wynikać $z$ faktu, że reszta Arg-206 ulega ADP-rybozylacji w aktynie monomerycznej, a reszta Arg-28 (zlokalizowana $\mathrm{w}$ subdomenie 1) jest modyfikowana 
w aktynie filamentowej (Tabela 1) (TERASHIMA i współaut. 1995).

Przyłaczone reszty ADP-rybozylowe usuwane sa przez hydrolaze ADP-rybozyloaktyny, natomiast niewiele wiadomo o mechanizmie działania tego enzymu (OKAMOTO i współaut. 1997, AKTORIES i współaut. 2011).

\section{ARGINYLACJA}

Arginylacja to wciąz mało poznany proces przenoszenia reszty arginylowej na reszty aminokwasowe w łańcuchu polipeptydowym białek (Ryc. 2), który zachodzi przy udziale transferazy arginylowej Ate1 (KASHINA 2006). Niewiele wiadomo o mechanizmach dearginylacji i uczestniczaccych $\mathrm{w}$ tym procesie enzymach; in vitro wykazano, że moga to być amino- lub karboksypeptydazy w przypadku, gdy arginylowana jest reszta na, odpowiednio, aminowym lub karboksylowym końcu łańcucha polipeptydowego albuminy (WANG i współaut. 2014). Badania ostatniej dekady wykazały, że wiele białek ulega arginylacji, $Z$ czego około $30 \%$ to białka cytoszkieletalne, $\mathrm{w}$ tym izoforma $\beta$ aktyny (WoNG i współaut. 2007). Dane uzyskane przy użyciu spektrometrii mas wykazały, że arginylacji ulegaja głównie reszty kwasu asparaginowego (Asp2 i/lub Asp3) znajdujące się na końcu aminowym $\beta$-aktyny (KASHINA 2006). Arginylacja wpływa na wydłużanie się filamentów i zapobiega tworzeniu przez nie wiazek i agregatów. Wykazano, że obniżenie poziomu, bądź wręcz zahamowanie możliwości arginylacji białek (w tym aktyny) prowadzi do zaburzenia migracji komórek i skurczu mięśni (KARAKOZOVA i współaut. 2006, RAI i współaut. 2008, Kurosaka i współaut. 2010). Myszy nie syntetyzujace Ate1 (Ate1-KO) umierały $z$ powodu defektów mięśnia sercowego, naczyń krwionośnych i grzebienia nerwowego (KWON i współaut. 2002, KUROSAKA i współaut. 2010). Z kolei w fibroblastach zauważono rozpad lamellipodium krawędzi wiodacej oraz spadek ilości F-aktyny, bez istotnych zmian w poziomie całkowitej aktyny (SAHA i współaut. 2010). Wprowadzenie do komórek Ate1-KO arginylowanej $\beta$-aktyny przywracało zdolność do tworzenia krawędzi wiodacej i migracji. Wykazano, że niearginylowana aktyna nie jest w stanie tworzyć sieci, typowej dla podbłonowej strefy lamellipodium, stąd zapewne obserwowane zmiany na froncie komórek. Co ciekawe, reszta Asp-2 ulega również acetylacji; obie te modyfikacje wzajemnie się wykluczają i decyzja, która $z$ grup, acetylowa czy arginylowa, zostanie przyłączona zachodzi prawdopodobnie kotranslacyjnie w kontekście stanu funkcjonalnego komórki.

Szereg innych reszt aminokwasowych $\beta$-aktyny także ulega arginylacji (Tabela 1).
Uważa się, że modyfikacja tych reszt może wpływać na proces polimeryzacji aktyny i jej oddziaływania $z$ białkami wiążacymi aktynę. Wciąż jednak niewiele wiemy, kiedy i w jaki sposób arginylowane sa reszty znajdujące się we wnętrzu cząsteczki $\beta$-aktyny.

Choć $\gamma$-aktyna może być również arginylowana, to jednak wysoce specyficzny dla tej izoformy aktyny mechanizm usuwa arginylowane białko już na poziomie translacji, tak aby jego arginylowana forma nie była obecna w komórce (ZHANG i współaut. 2010). Wciąż niewiele wiadomo dlaczego tak się dzieje, zwłaszcza że obie cytoplazmatyczne aktyny, tzn. $\beta$ - i $\gamma$-aktyna maja bardzo podobne i wręcz wymienne funkcje.

\section{FOSFORYLACJA}

Fosforylacja białek, czyli kowalencyjne przyłączenie reszty fosforanowej do reszt aminokwasowych (Ryc. 2), jest najczęściej występujaca modyfikacją potranslacyjna, kontrolujaca większość procesów zachodzących w komórkach. Enzymami, które katalizują fosforylację sa kinazy, które przenosza grupe fosforanowa $z$ ATP na grupe wodorotlenowa $w$ najczęściej fosforylowanych resztach seryny, treoniny lub tyrozyny. Aktyny również ulegają fosforylacji. Dotychczas zidentyfikowano fosforylację 35 reszt aminokwasowych (Tabela 1). O ile dość dużo wiadomo o wpływie fosforylacji aktyny na jej strukturę i funkcje u śluzowców, to wciąz niewiele wiemy o roli tej potranslacyjnej modyfikacji w aktynie u innych organizmów (TERMAN i KASHINA 2013).

Najlepiej scharakteryzowana jest fosforylacja aktyny śluzowców: Dictyostelium discoideum i Physarum polycephalum. W przypadku aktyny Dictyostelium fosforylacja zachodzi na reszcie Tyr-53, znajdujacej się w pobliżu pętli wiążącej DNazę I, ważnej dla oddziaływań pomiędzy protomerami aktyny w filamencie (BENDER i współaut. 1976). Fosforylacja tej reszty wpływa na proces polimeryzacji, prawdopodobnie przez stabilizacje pętli D poprzez tworzenie wiazań wodorowych $z$ grupa fosforanowa oraz zaburza oddziaływanie $z$ profilina. Fosforylacja reszty Tyr-53 wydaje się być kluczowa dla tego organizmu, w jego odpowiedzi na specyficzne bodźce prowadzące do stanu uśpienia (tworzenie zarodników). W przypadku Physarum fosforylacji z udziałem zależnej od jonów $\mathrm{Ca}^{2+}$ kinazy aktynowo-fragminowej (AFK) ulegaja trzy reszty treoninowe (Thr 201-203). Za proces odwrotny, defosforylacje, odpowiadaja fosfatazy $z$ grup PP1 i PP2A (WAELKEns i współaut. 1995). Fosforylowane reszty sa zachowane w toku 
ewolucji i znajduja się na końcu ostrym, w obrębie subdomeny 4 (Ryc. 1A), a ich fosforylacja prowadzi do przyśpieszenia etapu wydłużenia filamentów poprzez osłabienie oddziaływania aktyny $\mathrm{z}$ fragmina, jednym z białek regulujących proces polimeryzacji (WAELKENS i współaut. 1995). Sugeruje się również, że modyfikacja tych reszt może ułatwiać dodawanie monomerów do końca ostrego, do którego przyłączanie zachodzi dużo wolniej niż w przypadku końca kolczastego. Podobnie jak w przypadku aktyny Dictyostelium, u Physarum fosforylacja jest elementem odpowiedzi na bodźce zwiazane $z$ przejściem śluzowca $w$ stan uśpienia i może stanowić mechanizm adaptacyjny, modulujący przejście pomiędzy sporulacja i kiełkowaniem, przez umożliwienie szybkiej reorganizacji aktyny. Podobny efekt wywołuje $\mathrm{w}$ tych komórkach fosforylacja $z$ udziałem kinazy kazeinowej I, która fosforyluje te same reszty treoninowe (TERMAN i KASHINA 2013).

W przypadku aktyny ssaków zdecydowana większość informacji o miejscach fosforylacji pochodzi $z$ analiz proteomicznych, prowadzonych na różnych rodzajach komórek, w warunkach prawidłowych i patologicznych oraz $\mathrm{w}$ odpowiedzi komórek na różne bodźce (TERMAN i KASHINA 2013). W przypadku $\beta$-aktyny stwierdzono fosforylację tych samych reszt, co u wspomnianych tu śluzowców, a ogrom informacji na ten temat, przekracza ramy niniejszego opracowania (TERMAN i Kashina 2013). Przykładowo, zauważono, że fosforylacja szeregu reszt serynowych i treoninowych po stymulacji insulina, prowadzi do osłabienia wiazania przez aktynę DNazy I. Jak dotychczas nie zidentyfikowano kinazy odpowiedzialnej za fosforylacje $\mathrm{w}$ tych warunkach. $Z$ kolei fosforylacja aktyny przez kinazę PAK1 (ang. p21-activated kinase), aktywowana przez małe białka G, Cdc42 i Rac1, prowadzi do dysocjacji włókien naprężeniowych i redystrybucji filamentów aktynowych. Aktyna jest także fosforylowana przez kinazy tyrozynowe $z$ rodziny Src; prowadzi to również do depolimeryzacji filamentów. Najbardziej znane sa badania nad wpływem fosforylacji aktyny przez zależna od cAMP kinazę białkowa A (PKA) oraz przez zależna od jonów $\mathrm{Ca}^{2+} \mathrm{i}$ fosfoinozytoli kinazę białkowa C (PKC). Fosforylacja przez obie te kinazy wywiera przeciwstawny wplyw na aktynę. Podczas gdy działanie PKA zaburza proces polimeryzacji, to działanie PKC pobudza ten proces (OHTA i współaut. 1987). Wyniki te wskazuja zatem na istnienie dynamicznej zależności pomiędzy ścieżkami sygnałowymi regulowanymi przez obie te kinazy a zmia- nami w morfologii komórek wynikajacych $z$ reorganizacji aktyny.

\section{MODYFIKACJE Z UDZIAEEM GLUKOZY}

Aktyna, podobnie jak szereg innych białek, może być modyfikowana kowalencyjnie przez cukry. Najbardziej znana jest glikozylacja $z$ wytworzeniem wiazania N- lub O-glikozydowego (Ryc. 2), które to modyfikacje sa typowe dla białek błonowych, związanych $z$ procesami sekrecji i procesowania pęcherzyków błonowych. W proces ten zaangażowane sa dwa zachowane $\mathrm{w}$ toku ewolucji enzymy: O-GlcNAc transferaza (OGT) i O-GlcNAc hydrolaza (OGA), które w odpowiedzi na bodźce odpowiednio przyłączaja lub usuwaja reszte $\mathrm{N}$-acetyloglukozaminy $\mathrm{z}$ reszty serynowej lub treoninowej łańcucha polipeptydowego (HART i współaut. 2007).

Aktyna jest podatna na O-glikozylację, do której dochodzi zarówno w cytoplazmie, jak i w jądrze komórkowym (Ryc. 2, Tabela 1). Modyfikację tę wykryto zaledwie kilka lat temu, podczas analiz proteomicznych szczurów, którym już w życiu płodowym podawano alkohol (FOFANA i współaut. 2010). Glikozylacja aktyny wpływa na modulację skurczu mięśni poprzecznie prażkowanych, kardioprotekcje i zmiany $\mathrm{w}$ tkankach diabetyków (AKIMOTO i współaut. 2011).

Zmiany te sa podobne do zmian wywołanych przez glikację aktyny, która polega na nieenzymatycznym przyłączaniu glukozy do reszt lizynowych białka. Okazało się, że glikacji ulega nie tylko aktyna u diabetycznych pacjentów, ale również aktyna otrzymana $z$ mięśni szkieletowych królika (TERMAN i KASHINA 2013). Glikacja powoduje zaburzenia $\mathrm{w}$ procesie polimeryzacji aktyny, co w komórce przekłada się na zmiany kształtu i elastyczności komórek, zwłaszcza takich jak leukocyty. Dla przykładu, retinopatie u cukrzyków sa związane $z$ glikacja aktyny i $\mathrm{w}$ konsekwencji z zaburzeniami organizacji cytoszkieletu aktynowego granulocytów (RESMI i współaut. 2005, KUlEva i KovalEnKo 1997, TERMAN i KASHINA 2013). Prowadzi to do upośledzenia zdolności tych białych krwinek do przechodzenia przez ścianę naczyń krwionośnych, co powoduje zablokowanie światła naczyń włosowatych $\mathrm{w}$ siatkówce i w konsekwencji upośledzenie widzenia.

\section{METYLACJA}

Metylacja to enzymatyczne przeniesienie reszt metylowych $z$ S-adenozylometioniny na reszty aminokwasowe białek, najczęściej lizyny i argininy, przy udziale metylotransferaz (Ryc. 2). 
Aktyna ulega metylacji na His-73 (Tabela 1) i modyfikacja ta jest istotna dla zachowania giętkości i stabilności filamentów, poprzez regulację oddziaływań pomiędzy subdomenami poszczególnych protomerów w filamencie. Sugeruje się, że metylacja reszty His-73 spowalnia uwalnianie ze szczeliny katalitycznj ortofosforanu powstałego podczas hydrolizy ATP, co stabilizuje filament (VIJAYASARATHY i RAO 1987, RAGHAVAN i współaut. 1992). Zidentyfikowano metylazy modyfikujace aktynę, aczkolwiek nie ma pewności, czy faktycznie biora one udział w metylacji tej reszty, gdyż metylacji może równiė̇ ulegać reszta Lys-326, a także reszty już arginylowane (SAHA i współaut. 2011). Co ciekawe, obniżony poziom metylacji aktyny stwierdzono po transformacji komórek onkogenem, jakim jest kinaza Src (CHIOU i współaut. 2012). Wskazuje to na istotna rolę metylacji aktyny w jej funkcjonowaniu w komórkach prawidłowych i nowotworowych.

\section{MODYFIKACJE TYPU REDOX}

Pierwsze obserwacje o wpływie oksydacji aktyny pochodza $z$ lat 40 . ubiegłego stulecia, a więc tuż po wykryciu i oczyszczeniu tego białka $z$ mięśni szkieletowych. Stwierdzono wówczas, że dodanie $\mathrm{H}_{2} \mathrm{O}_{2}$ uniemożliwiało polimeryzację aktyny i prowadziło do destrukcji już istniejacych filamentów (FEUER i współaut. 1948). W kolejnych dekadach ukazały się liczne doniesienia wskazujace, że aktyna rzeczywiście jest podatna na modyfikacje potranslacyjne typu redox, takie jak: oksydacja (Ryc. 2), nitrozylacja, nitracja, karbonylacja i glutationylacja (Tabela 1) (WILSON i współaut. 2016). Stwierdzono, że podatność aktyny $\mathrm{w}$ warunkach in vitro na poszczególne typy modyfikacji redox zależy od tego, czy jest ona w formie monomerycznej czy spolimeryzowanej, od rodzaju zwiazanego przez nia nukleotydu i kationu dwuwartościowego oraz siły jonowej roztworu. Ta zależność może przekładać się na warunki in vivo, przy czym różne formy utlenienia aktyny moga stanowić o jej udziale w stanach patologicznych. Faktycznie, zaobserwowano, iż stres oksydacyjny wpływa na organizację aktyny w komórce i generuje powstanie wielu modyfikacji typu redox. Ponadto, w wielu schorzeniach, $\mathrm{np}$. w chorobach neurodegeneracyjnych, cukrzycy, zaburzeniach krażenia, gruźlicy płuc czy anemii sierpowatej zidentyfikowano $\mathrm{w}$ aktynie szereg modyfikacji oksydacyjnych, co sugeruje ich powiazanie $z$ etiopatogeneza tych schorzen (TERMAN i KASHINA 2013, WILSON i współaut. 2016). Należy jednak zdawać sobie sprawę, że w stanach prawidłowych moga występować podobne modyfikacje, które sa wynikiem akty- wacji specyficznych szlaków przekazywania sygnałów. Mimo licznych doniesień, fizjologiczne znaczenie modyfikacji potranslacyjnych typu redox jest wciąż mało poznane i badania powinny skupić się na poznaniu zależności pomiędzy miejscem i rodzajem modyfikacji a wpływem na funkcjonowanie aktyny in vivo.

W łańcuchu polipeptydowym aktyny znajduje się pięć reszt cysteinowych, które sa podatne na reaktywne formy tlenu, azotu i lipidów (Tabela 1), przy czym zlokalizowana na w końcu karboksylowym reszta Cys-374 jest najbardziej aktywna i ulega oksydacji, glutationylacji, karbonylacji i nitrozylacji. W oczyszczonym białku reszta ta jest utleniana wskutek ekspozycji na powietrze, w trakcie przechowywania oraz w czasie cyklu rozmrażania lub zamrażania próbki; co prowadzi do tworzenia mostków dwusiarczkowych pomiędzy monomerami aktyny (WILSON i współaut. 2016). Dla zahamowania procesu utleniania do roztworu aktyny dodaje się czynnik redukujący, zazwyczaj jest to ditiotreitol (DTT). Modyfikacje typu redox sa również związane $z$ tworzeniem wewnętrznych mostków dwusiarczkowych w monomerze aktyny i prowadza do zahamowania tempa polimeryzacji, wzrostu stężenia krytycznego (tzn. takiego, poniżej którego aktyna nie jest $\mathrm{w}$ stanie polimeryzować) oraz osłabienia struktury filamentów powstałych $z$ modyfikowanej aktyny. Powoduje to zmiany $\mathrm{w}$ cytoszkielecie aktynowym, co zaobserwowano $w$ sierpowatych erytrocytach $u$ pacjentów $z$ tym typem anemii (SHARTAVA i współaut. 1995). Natomiast wysoka reaktywność reszty Cys-374 i jej zdolność do oddziaływania ze znacznikami fluorescencyjnymi (np. pyrenylem) jest wykorzystywana do badania właściwości samej aktyny i jej oddziaływań $z$ innymi białkami. Również modyfikacja reszt Cys-272 i Cys-285, znajdujących się wewnątrz sfałdowanej cząsteczki, prowadzi do obniżenia poziomu polimeryzacji i zaburzeń $\mathrm{w}$ wiązaniu oddziałujących $\mathrm{z}$ aktyna białek (Tabela 1). Stwierdzono także, $\mathrm{iż} \mathrm{w}$ warunkach in vitro oksydowana reszta Cys-285 może tworzyć mostek dwusiarczkowy $z$ aktywna reszta Cys-374, co skutkuje tworzeniem miedzycząsteczkowych dimerów i krótkich oligomerów, a w konsekwencji zahamowaniem polimeryzacji aktyny (SHARTAVA i współaut. 1995).

Część z 16. reszt metioniny w cząsteczce aktyny jest także podatna na oksydacje (Tabela 1), a ich modyfikacja prowadzi do zaburzenia funkcji białka (WILSON i współaut. 2016). Modyfikacja reszty Met-44, znajdujaccej się w pętli wiażącej DNazę I, z jednej strony depolimeryzuje filamenty, a $z$ drugiej, hamuje polimeryzację de novo (HUNG i 
współaut. 2011). Oksydacja reszty Met-44 wprowadza ujemny ładunek w oddziaływania między protomerami, co prowadzi do zaburzenia tych oddziaływań i w konsekwencji rozpadu filamentu (HUNG i współaut. 2011). Należy zwrócić uwagę, że reszta ta jest schowana wewnatrz filamentu i w zasadzie nie powinna być dostępna dla czynników utleniających. Nasuwa się więc przypuszczenie, że pewne warunki panujące w komórce zmieniaja konformację filamentu, czyniąc tę resztę bardziej podatna na działanie czynników utleniających (WILSON i współaut. 2016).

Stwierdzono, że specyficzne reszty tyrozyny, histydyny i tryptofanu $\mathrm{w}$ czasteczce aktyny sa również podatne na modyfikacje typu redox, aczkolwiek wpływ tych zmian na funkcje aktyny nie został jak dotąd opisany (Tabela1).

Wiadomo, że wiele zwiazków chemicznych i czynników utleniających w komórce wpływa na strukturę i funkcje aktyny, natomiast nie wiemy, czy sa procesy redox specyficznie „atakujace” tylko to białko. Dla przykładu, enzymy, które generuja reaktywne formy tlenu, azotu i lipidów sa zwiazane $z$ modyfikacjami aktyny, jednak $z$ powodu ich niespecyficzności i opartego na dyfuzji mechanizmu uwalniania reaktywnych form, to aktyna, jako wszechobecne w komórce białko, jest jednym $z$ wielu modyfikowanych białek. Ta wszechobecność i obfitość może do pewnego stopnia czynić aktynę niespecyficznym „zmiataczem” reaktywnych form, chroniacym komórke przed szkodliwym działaniem endogennych oksydantów. Natomiast niektóre $z$ enzymów, jak np. syntaza tlenku azotu (NOS), oksydaza NADPH i 5-lipooksygenaza, nie tylko kolokalizuja $z$ aktyna (KANG i VANDERHOEK 1998, WILSON i współaut. 2016), ale i ich aktywność jest regulowana przez aktynę (MILler i współaut. 2001, Su i współaut. 2007).

Co więcej wykryto, iż wielodomenowy enzym, monooksygenaza flawinowa (Mical), specyficznie modyfikuje aktynę (HUNG i współaut. 2010, 2011). Ten znajdujący się $\mathrm{w}$ cytoplazmie enzym bierze udział w ukierunkowanym rozwoju/wzroście komórek (np. nakierowywaniu aksonów), który jest zależny od semaforyn, białek błonowych kontrolujacych szlaki przekazywania sygnałów. Enzym ten, oddziałuje poprzez koniec karboksylowy $z$ pleksyna, receptorem dla semaforyn, podczas gdy znajdująca się na końcu aminowym domena monooksygenazowa wiaże się bezpośrednio $z$ aktyną (HUNG i współaut. 2010, Hung i Terman 2011). Wiazanie F-aktyny aktywuje Mical, co powoduje oksydacje reszt Met-44 i Met-47 w aktynie, a w konsekwencji prowadzi do depolimeryzacji filamentów i zahamowania polimeryzacji (HUNG i współaut. 2011). Modelowanie molekularne wykazało, że miejsce katalityczne tego enzymu mieści się w szczelinie między protomerami aktyny, co prawdopodobnie umożliwia jego dostęp do tych trudno dostępnych reszt aminokwasowych i ich modyfikację. $Z$ kolei zamiana reszty Met-44 na leucynę zaburza regulację organizacji aktyny poprzez Mical, prowadzacc do akumulacji nieprawidłowych struktur aktynowych w komórce (HuNG i TERMAN 2011, HUNG i współaut. 2011).

\section{SIECIOWANIE}

Sieciowanie (ang. crosslinking) filamentów aktynowych to nieenzymatyczny proces zachodzący w każdej komórce, niezbędny dla pożądanej $\mathrm{w}$ danym momencie $\mathrm{i} \mathrm{w}$ danym przedziale komórki organizacji cytoszkieletu aktynowego. Biora w tym udział białka sieciujace takie, jak np. filamina, spektryna, fascyna czy a-aktynina, które umożliwiaja tworzenie sieci i/lub wiazek filamentów aktynowych (POLlARD i COOPER 2009). Okazało się natomiast, że również bakterie, zwłaszcza te patogenne, sa zdolne do nieplanowanego, często nadmiernego sieciowania aktyny $\mathrm{w}$ zainfekowanej komórce, co ma negatywne skutki dla jej funkcjonowania. Jednym $z$ przykładów jest kowalencyjne sieciowanie monomerów aktyny $\mathrm{w}$ oligomery przez toksyny MARTX i VgrG-1 przecinkowca cholery (Vibrio cholerae), co powoduje spadek dostępnej F-aktyny. Prowadzi to do zaokraglenia komórki i, w konsekwencji, jej śmierć (Tabela 1) (AKTORIEs i współaut. 2011). W sieciowanie zaangażowane sa reszty Lys-50 $z$ jednego protomeru i Glu-270 z drugiego protomeru (KUDRYASHOV i współaut. 2008). Obie te reszty znajduja się $\mathrm{w}$ rejonach istotnych dla tworzenia filamentu.

Innym czynnikami sieciujacymi aktyne sa transglutaminazy (TGazy), które modyfikuja resztę Gln-41 i indukuja jej sieciowanie $z$ innymi resztami $w$ czasteczce aktyny, np. $z$ reszta Lys-50 w tym samym monomerze (sieciowanie wewnątrzcząsteczkowe) lub $z$ reszta Lys-113 w sasiednim protomerze (sieciowanie międzycząsteczkowe) (Tabela 1). TGazy mogą również sieciować aktynę $z$ innymi białkami i związkami niskocząsteczkowymi, co zostało także wykorzystane jako narzędzie do badania właściwości aktyny. Sieciowanie przez TGazy stabilizuje filamenty aktynowe, czyniąc je bardziej odpornymi na depolimeryzację, fragmentacje i działanie proteaz. Zaobserwowano wplyw działania TGaz na zwiąane $z$ cytoszkieletem aktynowym procesy takie jak: sekrecja insuliny, wzrost łagiewki pyłkowej, przekazywanie sygnału przez czynniki wzrostu, apoptoza, a także funkcjonowanie komórek neuronalnych 
w śródbłonku (TERMAN i KASHINA 2013). Postuluje się, że TGazy w pyłkach kontroluja równowagę pomiędzy krótkimi i niestabilnymi filamentami a stabilnymi wiazkami F-aktyny na pograniczu wierzchołka i u podstawy wydłużającej się łagiewki (DEL DUCA i współaut. 2009). TGazy wpływaja pośrednio również na funkcjonowanie szeregu białek zwiąanych $z$ aktyna, np. miozyny, gdyż transglutaminowana aktyna słabiej wiąże się $z$ domena motoryczna miozyny i tym samym aktywność ATPazowa miozyny jest obniżona (DEL DuCA i współaut. 2009).

\section{MODYFIKACJA MAŁYMI BIAŁKAMI: UBIKWITYNACJA, SUMO-ILACJA I ISG-ILACJA}

Aktyna, podobnie jak znaczna część białek, może być ubikwitynowana i SUMO-ilowana (Tabela 1) oraz ISG-ilowana, czyli zawierać kowalencyjnie przyłączone do grupy wodorotlenowej reszt lizynowych niskoczasteczkowe białka takie, jak ubikwityna (m.cz. ok. 8.6 kDa), SUMO (m.cz. ok. 12 $\mathrm{kDa}$ ) lub ISG15 (m.cz. ok. $17 \mathrm{kDa}$ ). Procesy te sa kilkuetapowe, katalizowane przez trzy grupy enzymów: E1 (zależny od ATP; w przypadku ubikwitynacji to enzym aktywujacy ubikwitynę), E2 (w przypadku ubikwitynacji to enzym koniugujacy ubikwitynę) oraz E3 (w przypadku ubikwitynacji to enzym ligaza ubikwityna-białko). Niewiele wiadomo o procesie odwrotnym, który również wymaga obecności specyficznych enzymów. Dla przykładu, zidentyfikowano enzymy SENP/Ulp, które nie degradujac kompleksu SUMO-białko, usuwaja SUMO poprzez przecinanie wiazania peptydowego pomiędzy glicyna w SUMO a modyfikowana lizyna (ALONso i współaut. 2015).

Białka moga ulegać monoukwibitynacji, czyli przyłączeniu monomeru ubikwityny do jednej lub więcej reszt, oraz poliubikwitynacji, czyli przyłączeniu łańcucha czasteczek ubikwityny (poliubikwityny) do jednej reszty aminokwasowej (Ryc. 2). Poliubikwitynacja kieruje białka do degradacji proteasomalnej, natomiast monoubikwitynacja wydaje się determinować specyficzne funkcje tak modyfikowanych białek (FINLEY i CHAU 1991).

Aktyna także ulega poliubikwitynacji przez enzymy takie, jak MuRF1 i Trim32 (ligazy E3) oraz UbcH5 (enzym E2) (KUDRYASHOVA i współaut. 2005, COHEN i współaut. 2009, Polge i współaut. 2011), co w konsekwencji prowadzi do obniżenia poziomu aktyny w komórce. Indukowana poliubikwitynacja degradacja aktyny jest szczególnie intensywna $\mathrm{w}$ procesach zwiazanych $\mathrm{z}$ patologia mięśni (KUDRYASHOVA i współaut. 2005, COHEN i współaut. 2009, POLGE i współaut.
2011). W przeciwieństwie do poliubikwitynacji, monoubikwitynacja jest uważana za czynnik stabilizujacy aktynę i warunkujący jej lokalizację komórkowa (DANTAN-GONZALEZ i współaut. 2001). Na przykład, u Drosophila reszta Lys-118 aktyny mięśni skrzydeł jest monoubikwitynowana na co siódmym protomerze filamentu cienkiego i modyfikacja ta wydaje się regulować siłę skurczu mięśni (BuRGESS i współaut. 2004).

SUMO-ilacja, czyli przyłączanie białka SUMO (ang. small ubiquitin-like modifier) (Ryc. 2) zachodzi w przypadku aktyny najprawdopodobniej na reszcie Lys-284, znajdujacej się w subdomenie 3. Modyfikacja ta jest odpowiedzialna za obecność aktyny w jądrze komórkowym, poprzez blokowanie miejsca determinujacego eksport aktyny $z$ jądra (ang. nuclear export sequence, NES) (Alonso i współaut. 2015). Uważa się również, że SUMO-ilacja uniemożliwia tworzenie klasycznych filamentów aktynowych, co wydaje się tłumaczyć obecność w nukleoplazmie krótszych, nieprawidłowo spolimeryzowanych filamentów, nie występujacych w cytoplazmie (HOFMANN i współaut. 2009).

Ponadto stwierdzono, że do aktyny moga przyłączać się reszty białka ISG15 (ang. interferon stimulated gene-15), co świadczy, że ulega ona ISG-ilacji, aczkolwiek rola tej niedawno wykrytej modyfikacji dla funkcjonowania aktyny jest nieznana. Synteza ISG15, małego białka sekrecyjnego, jest podwyższona podczas leczenia interferonem i wskutek infekcji wirusowych. Uważa się więc, iż ISG-ilacja jest zwiazana $z$ procesami zapalnymi (ZHANG i ZHANG 2011).

\section{INNE MODYFIKACJE}

Aktyna jest również podatna na szereg innych modyfikacji potranslacyjnych, których znaczenie dla funkcjonowania tego białka jest mało znane (TERMAN i KASHINA 2013).

Stwierdzono, że aktyna ulega izoaspartylacji, czyli izomeryzacji reszt Asp-25 i Asp179 (Tabela 1), oraz do deamidacji tych reszt (Cimmino i współaut. 2008). Białko to może być również substratem dla metylotransferazy L-izoaspartylu (PIMT), która powoduje zamianę reszty izoaspartylowej ponownie w aspartylowa (ZHU i współaut. 2006).

Aktyna podlega także enzymatycznym procesom acylacji/alkanoilacji takim, jak mirystoilacja i palmitoilacja, co sugeruje możliwość oddziaływania tak zmodyfikowanej aktyny z lipidami błony komórkowej (STADLER i współaut. 1985, BANO i współaut. 1998).

Aktyna może także podlegać fragmentacji proteolitycznej i zdarza się, że proteoliza i acylacja resztami kwasów tłuszczowych wy- 
stępuja jednocześnie. Przykładem tego jest działanie kaspaz (enzymów proteolitycznych, których aktywacja prowadzi do apoptozy), które inicjuja myristoilacje aktyny, co prowadzi do kierowania jej do mitochondriów i zaangażowanie $\mathrm{w}$ procesie apoptozy (UTSUMI i współaut. 2003).

Aktyna może być również siarczanowana (tzn. zawierać przyłączone kowalencyjnie reszty siarczanowe). Nie wiadomo, jak ten proces wpływa na jej funkcjonowanie, wiadomo natomiast, $\dot{z} \mathrm{e}$ sulfotransferazy wiąża się z F-aktyna i moga ja wykorzystywać jako platformę do rekrutowania hydroksysteroidów (np. cholesterolu) w celu przyłączenia do nich reszty siarczanowej w określonych przedziałach komórki (KUROGI i współaut. 2010). Wykazano również, że do reszt cysteinowych aktyny moga być przyłączone reszty sulfohydrylowe (tiolowe) i modyfikacja ta, katalizowana przez $\mathrm{Y}$-liazę cystationinowa (CSE), stymuluje polimeryzację aktyny (MUSTAFA i współaut. 2009).

Stwierdzono też, że do aktyny moga być kowalencyjnie przyłaczane $\mathrm{w}$ warunkach in vitro reszty kwasu bursztynowego (bursztynylacja) oraz in vivo - kwasu malonowego (malonylacja; przyłączanie do reszty Lys-61), które to modyfikacje moga potencjalnie regulować organizację aktyny (TERMAN i KASHINA 2013). Nie ma doniesień o wpływie tych modyfikacji na strukturę i funkcje aktyny.

\section{PODSUMOWANIE}

Przedstawione informacje, będace zaledwie krótkim streszczeniem dostępnej wiedzy wskazuja, że aktyna, jedno $z$ najpowszechniej występujacych i najistotniejszych dla życia białek, jest podatna na większość $z$ dotychczas poznanych modyfikacji translacyjnych. Modyfikacje te wpływaja lub moga potencjalnie wpływać na jej strukturę i funkcjonowanie w komórce, co przyczynia się do jeszcze większej złożoności kontroli organizacji tego białka, które przecież jest także regulowane przez plejade białek zdolnych do wiazania aktyny. Wciąż niewiele wiadomo o wpływie większości ze zidentyfikowanych modyfikacji na strukturę i funkcje aktyny oraz związku tych modyfikacji $\mathrm{z}$ udziałem aktyny $\mathrm{w}$ stanach fizjologicznych i patologicznych. Nie wiemy też, dlaczego natura wykształciła dodatkowe sposoby regulacji aktyny, wymagajace $\mathrm{w}$ większości wypadków obecności dodatkowych białek i nakładu energii. Czemu służy tak ogromna, wielopoziomowa sieć regulacji i oddziaływań. Co więcej, należy też zdawać sobie sprawę, że modyfikacjom potranslacyjnym ulegaja też białka oddziałujace $\mathrm{z}$ aktyna. Czy taka złożoność jest niezbędna do zapewnienia/zabezpieczenia dynamiki reorganizacji tworzonych przez aktynę struktur?

Nasuwa się też wiele bardziej szczegółowych pytań, że wspomnę tylko o kilku z nich. Na przykład, dlaczego i w jakiej kolejności te same reszty aminokwasowe moga ulegać różnym, często przeciwstawnym w działaniu modyfikacjom, jak to ma miejsce w przypadku acetylacji i arginylacji. Odpowiedzi wymaga też pytanie, czy pewne rejony czasteczki sa bardziej podatne na modyfikacje $\mathrm{w}$ formie monomerycznej czy filamentowej. Czy inne modyfikacje poza transglutaminacja i acetylacja wpływaja na oddziaływanie aktyny $z$ miozynami, a zwłaszcza z tymi niekonwencjonalnymi, które biora udział $\mathrm{w}$ transporcie wewnatrzkomórkowym.

Odpowiedź na przynajmniej część $z$ tych pytań staje się możliwa wraz z rozwojem nowoczesnych technik biologii komórkowej i molekularnej oraz zaawansowanej proteomiki, aczkolwiek należy zdawać sobie sprawę, że złożoność zagadnień nie ułatwia zadania. Osoby zainteresowane odsyłam do artykułu przeglądowego TERMANA i KASHINY (2013), który jest jedynym jak dotąd, tak wszechstronnym opracowaniem tego interesujaccego zagadnienia. Artykuł ten stanowił inspiracje do przygotowania przedstawionego artykułu.

$$
\text { Streszczenie }
$$

Aktyna, komponent cytoszkieletu komórek eukariotycznych, to jedno $z$ białek najistotniejszych dla funkcjonowania organizmów i najlepiej zachowanych w toku ewolucji. Ta globularna czasteczka o masie czasteczkowej około 42,3 $\mathrm{kDa}$ występuje zarówno w formie monomerycznej, jak i spolimeryzowanej (filamenty), a zdolność do dynamicznej reorganizacji aktyny jest niezbędna dla życia komórki. Przejście pomiędzy obiema formami jest możliwe dzięki precyzyjnej w czasie i przestrzeni, dynamicznej regulacji organizacji aktyny przez szereg białek wią̇ących się zarówno $z$ monomerami, jak i filamentami aktyny. Istotnym czynnikiem wpływającym na stopień spolimeryzowania aktyny sa także liczne modyfikacje potranslacyjne tego białka. Niniejszy artykuł przeglądowy jest poświęcony omówieniu tego obszernego i wciąż mało poznanego zagadnienia, a w szczególności opisowi jakim modyfikacjom ulega aktyna i $\mathrm{w}$ jaki sposób modyfikacje te wplywaja na strukturę i funkcje tego wyjattkowego białka.

\section{LITERATURA}

AKimoto Y., MiURA Y., TOda T., Wolfert M. A., WELls L., BOONS G. J., HART G. W., ENDO T., KAWAKAMI H., 2011. Morphological changes in diabetic kidney are associated with increased OGlcNAcylation of cytoskeletal proteins including alpha-actinin 4. Clin. Proteomics 8, 15.

AKTORIES K., LANG A. E., Schwan C., MANNHERZ H. G., 2011. Actin as target for modification by bacterial protein toxins. FEBS J. 278, 4526-4543.

Alonso A., Greenlee M., Matts J., Kline J., DAVIS K. J., MilleR R. K., 2015. Emerging roles of sumoylation in the regulation of actin, 
microtubules, intermediate filaments, and septins. Cytoskeleton 72, 305-339.

BANO M. C., JACKSON C. S., MAGEE A. I., 1998. Pseudo-enzymatic Sacylation of a myristoylated yes protein tyrosine kinase peptide in vitro may reflect non-enzymatic S-acylation in vivo. Biochem. J. 330, 723-731.

Belin B. J., Mullins R. D. 2013. What we talk about when we talk about nuclear actin. Nucleus 4, 291-297.

Bender N., FASOld H., KenMoKu A., MiddelhofF G., VOLK K. E., 1976. The selective blocking of the polymerization reaction of striated muscle actin leading to a derivative suitable for crystallization. Modification of Tyr-53 by 5-diazonium- $(1 \mathrm{H})$ tetrazole. Eur. J. Biochem. 64, 215-218

Blanchoin L., BoujemaA-Paterski R., Sykes C., Plastino J., 2014. Actin dynamics, architecture, and mechanics in cell motility. Physiol. Rev. 94, 235-263.

Burgess S., WALKer M., KNight P. J., SPARRow J., Schmitz S., OfFER G., Bullard B., LEONARD K., HOLT J., TRINICK J., 2004. Structural studies of arthrin: monoubiquitinated actin. J. Mol. Biol. 341, 1161-1173.

ChiOU Y. Y., FU S. L., LIN W. J., LIN C. H., 2012. Proteomics analysis of in vitro protein methylation during Src-induced transformation. Electrophoresis 33, 451-461.

Cimmino A., Capasso R., Muller F., SAmbri I., Masella L., Raimo M., De Bonis M. L., D'ANGELO S., ZAPPIA V., Galletti P., IngRosso D., 2008. Protein isoaspartate methyltransferase prevents apoptosis induced by oxidative stress in endothelial cells: role of $\mathrm{Bcl}-\mathrm{Xl}$ deamidation and methylation. PLoS One 3, e3258.

Cohen S., Brault J. J., Gygi S. P., Glass D. J., VAlenzuela D. M., GaRTNER C., LATRES E., GOLDBERG A. L., 2009. During muscle atrophy, thick, but not thin, filament components are degraded by MuRF1-dependent ubiquitylation. J. Cell Biol. 185, 1083-1095.

COOK R. K., SHEFF D. R., RUBENSTEIN P. A., 1991 Unusual metabolism of the yeast actin amino terminus. J. Biol. Chem. 266, 16825-16833.

DANTAN-GONZALEZ E., ROSENSTEIN Y., QUiNTO C., SANCHEZ F., 2001. Actin monoubiquitylation is induced in plants in response to pathogens and symbionts. Mol. Plant Microbe Interact. 14, 1267-1273.

DEL DuCA S., SERAFINI-FraCASSINI D., BONNER P., CRESTI M., CAI G. 2009. Effects of post-translational modifications catalysed by pollen transglutaminase on the functional properties of microtubules and actin filaments. Biochem. J. 418, 651-664.

Feuer G., Molnar F., PettKo E., Straub F. B., 1948. Studies on the composition and polymerization of actin. Hung. Acta Physiol. 1, 150163.

Finley D., ChaU V., 1991. Ubiquitination. Annu. Rev. Cell Biol. 7, 25-69.

Fofana B., YaO X.H., Rampitsch C., Cloutier S. WiLKINS J. A., NYOMBA B. L., 2010. Prenatal alcohol exposure alters phosphorylation and glycosylation of proteins in rat offspring liver. Proteomics 10, 417-434.

HaRT G. W., HOUSLEY M. P., Slawson C., 2007. Cycling of O-linked beta- $N$-acetylglucosamine on nucleocytoplasmic proteins. Nature 446, 1017-1022.

HeRman I. M., 1993. Actin isoforms. Curr. Opin. Cell Biol. 5, 48-55.

Hofmann W. A., ARduini A., Nicol S. M., CAMACHO C. J., Lessard J. L., Fuller-PaCe F. V.,
DE LANEROLLE P., 2009. SUMOylation of nuclear actin. J. Cell Biol. 186, 193-200.

Hung R. J., TERMAN J. R. 2011. Extracellular inhibitors, repellents, and Semaphorin/Plexin/ MICAL-mediated actin filament disassembly. Cytoskeleton 68, 415-433.

HUNG R. J., YAZDANI U., YOON J., WU H., YANG T., GuPTA N., HuANG Z., VAN Berkel W. J., TERMAN J. R., 2010. Mical links semaphorins to F-actin disassembly. Nature 463, 823-827.

Hung R. J., PAK C. W., TERMAN J. R., 2011. Direct redox regulation of $F$-actin assembly and disassembly by Mical. Science 334, 17101713.

Just I., SEHR P., Jung M., VAN DAMME J., PuYPE M., VANDEKERCKHOVE .J, Moss J., AKTORIES K., 1995. ADP-ribosyltransferase type A from turkey erythrocytes modifies actin at Arg-95 and Arg-372. Biochemistry 34, 326-333.

KANG L. T., VANDERHOEK J. Y., 1998. Mono(S)hydroxy fatty acids: novel ligands for cytosolic actin. J. Lipid Res. 39, 1476-1482.

Karakozova M., KozaK M., Wong C. C. L., BaIley A. O., Yates J. R., Mogilner A., Zebroski H., KASHINA A., 2006. Arginylation of beta-actin regulates actin cytoskeleton and cell motility. Science 313, 192-196.

KashiNA A. S., 2006. Differential arginylation of actin isoforms: the mystery of the actin $N$-terminus. Trends Cell Biol. 16, 610-615.

KOVACS J. J., HUBBERT C., YAO T. P., 2004. The HDAC complex and cytoskeleton. Novartis Found Symp. 259;170-177; dyskusja 178-181, 223-175.

Kudryashov D. S., Durer Z. A., YtTerberg A. J., SAWAYA M. R., PASHKOV I., PROCHAZKOVA K., YeATES T. O., LOO R. R., LOO J. A., SATCHELl K. J., REISLER E., 2008. Connecting actin monomers by iso-peptide bond is a toxicity mechanism of the Vibrio cholerae MARTX toxin. Proc. Natl. Acad. Sci. USA 105, 18537-18542

KUDRYASHOVA E., KUDRYASHOV D., KRAMEROVA I., SPENCER M. J., 2005. Trim32 is a ubiquitin ligase mutated in limb girdle muscular dystrophy type $2 \mathrm{H}$ that binds to skeletal muscle myosin and ubiquitinates actin. J. Mol. Biol. 354, 413-424.

Kuleva N. V., Kovalenko Z. S., 1997. Change in the functional properties of actin by its glycation in vitro. Biochemistry 62, 1119-1123.

KUROGi K., SAKAKIBARA Y., KAMEMOTO Y., TAKAHASHI S., YASUdA S., LIU M. C., SUIKo M., 2010. Mouse cytosolic sulfotransferase SULT2B1b interacts with cytoskeletal proteins via a proline/serine-rich Cterminus. FEBS J. 277, 38043811.

Kurosaka S., Leu N.A., Zhang F., Bunte R., SAHA S., WANG J., GUO C., HE W., KashinA A., 2010. Arginylation-dependent neural crest cell migration is essential for mouse development. PLoS Genet 6, e1000878.

KWON Y. T., Kashina A. S., DAvydov I. V., Hu R. G., AN J. Y., SEO J. W., DU F., VARShaVSKY A., 2002. An essential role of $N$-terminal arginylation in cardiovascular development. Science 297, 96-99.

Miller Y. I., Chang M. K., FunK C. D., FeramiSCO J. R., WiTZTUM J. L., 2001. 12/15-lipoxygenase translocation enhances site-specific actin polymerization in macrophages phagocytosing apoptotic cells. J. Biol. Chem. 276, 19431-19439.

Montecucco C., RasotTo M. B., 2015. On botulinum neurotoxin variability. MBio 6, e02131-14 
MotTet D., CAstronovo V., 2008. Histone deacetylases: target enzymes for cancer therapy. Clin. Exp. Metastasis 25, 183-189.

Mustafa A. K., Gadalla M. M., Sen N., Kim S., Mu W., Gazi S. K., BarRow R. K., YANG G., WANG R., SNYDER S. H., 2009. H S signals through protein S-sulfhydration. Sci. Signal. 2, ra72.

OdA T., IWASA M., AiHARA T., MAEdA Y., NARITA A., 2009. The nature of the globular- to fibrous-actin transition. Nature 457, 441-445.

OHTA Y., AKIYAMA T., NISHIDA E., SAKAI H., 1987: Protein kinase $C$ and $c A M P$-dependent protein kinase induce opposite effects on actin polymerizability. FEBS Lett. 222, 305-310.

Okamoto H., Fujita H., Matsuyama S., Tsuyama S., 1997. Purification, characterization, and localization of an ADP-ribosylactin hydrolase that uses ADP-ribosylated actin from rat brains as a substrate. J. Biol. Chem. 272, $28116-28125$.

OKAZAKI I. J., MOSS J., 1996. Mono-ADP-ribosylation: a reversible posttranslational modification of proteins. Adv. Pharmacol. 35, 247-280.

OTTERBEIN L. R., GRACEFFA P., DOMINGUEZ R., 2001. The crystal structure of uncomplexed actin in the ADP state. Science 293, 708-711.

PERRIN B. J., ERVASTI J. M., 2010. The actin gene family: function follows isoform. Cytoskeleton 67, 630-634.

Polge C., Heng A. E., Jarzaguet M., Ventadour S., Claustre A., Combaret L., Bechet D., MATONDO M., UTTENWEILER-JOSEPH S., MONSARRAT B., ATTAIX D. TAILLANDIER D., 2011. Muscle actin is polyubiquitinylated in vitro and in vivo and targeted for breakdown by the E3 ligase MURF1. FASEB J. 25, 3790-3802.

Pollard T. D., COOPER J. A., 2009. Actin, a central player in cell shape and movement. Science 326, 1208-1212.

RAGHAVAN M., LindBERG U., SchutT C., 1992. The use of alternative substrates in the characterization of actin-methylating and carnosine-methylating enzymes. Eur. J. Biochem. 210, 311-318.

Rai R., Wong C. C., Xu T., Leu N. A., Dong D. W., GuO C., MCLaughlin K. J., Yates J. R. 3RD, KASHINA A. 2008. Arginyltransferase regulates alpha-cardiac actin function, myofibril formation and contractility during heart development. Development 135, 3881-3889.

Resmi H., AKHunlar H., TEMiz ARTMAnN A., GuNER G., 2005. In vitro effects of high glucose concentrations on membrane protein oxidation, G-actin and deformability of human erythrocytes. Cell Biochem. Funct. 23, 163-168.

SAHA S., Mundia M. M., Zhang F., Demers R. W., Korobova F., Svitkina T., Perieteanu A. A., DaWson J. F., Kashina A., 2010. Arginylation regulates intracellular actin polymer level by modulating actin properties and binding of capping and severing proteins. Mol. Biol. Cell $21,1350-1361$

SAHA S., Wong C. C., Xu T., NAmgoong S., ZEBROSKI H., YATES J. R. 3RD, KASHINA A., 2011. Arginylation and methylation double up to regulate nuclear proteins and nuclear architecture in vivo. Chem. Biol. 18, 1369-1378.

SCHMiTZ S., ClaYTON J., NONGTHOMBA U., PRINZ H., Veigel C., Geeves M., SparRow J., 2000. Drosophila ACT88F indirect flight muscle-specific actin is not $N$-terminally acetylated: a mutation in $N$-terminal processing affects actin function. J. Mol. Biol. 295, 1201-1210.
SHAEVITZ J. W., GITAI Z., 2010. The structure and function of bacterial actin homologs. Cold Spring Harb Perspect Biol 2, a000364.

SHARTAVA A., MONTEIRO C. A., BENCSATH F. A., SCHNEIDER K., Chait B. T., Gussio R., CASORIA-SCOTT L. A., SHAH A. K., HEUERMAN C. A., GOODMAN S. R., 1995. A posttranslational modification of beta-actin contributes to the slow dissociation of the spectrin-protein 4.1-actin complex of irreversibly sickled cells. J. Cell Biol. 128, 805-818.

Stadler J., Gerisch G., BAuer G., Deppert W., 1985. In vivo acylation of Dictyostelium actin with palmitic acid. EMBO J. 4, 1153-1156.

StARHEIM K. K., GevaerT K., ARnEsen T., 2012. Protein N-terminal acetyltransferases: when the start matters. Trends Biochem. Sci. 37, $152-161$

Su Y., KonDRIKOV D., BLOCK E. R., 2007. $\beta$-actin: a regulator of NOS-3. Sci. STKE 2007, pe52.

Terashima M., Yamamori C., Shimoyama M., 1995. ADP-ribosylation of Arg28 and Arg206 on the actin molecule by chicken arginine-specific ADP-ribosyltransferase. Eur. J. Biochem. 231, 242-249.

TERMAN J. R., KASHINA A., 2013. Post-translational modification and regulation of actin. Curr. Opin. Cell Biol. 25, 30-38.

Utsumi T., SAKURAI N., NAKANO K., Ishisaka R., 2003. C-terminal $15 \mathrm{kDa}$ fragment of cytoskeletal actin is posttranslationally Nmyristoylated upon caspase-mediated cleavage and targeted to mitochondria. FEBS Lett. 539, 37-44.

VANDEKERCKHOVE J., WEBER K., 1978. Mammalian cytoplasmic actins are the products of at least two genes and differ in primary structure in at least 25 identified positions from skeletal muscle actins. Proc. Natl. Acad. Sci. USA 75, 1106-1110.

ViJAYASARATHY C., RAO B. S., 1987. Partial purification and characterisation of S-adenosylmethionine: protein-histidine $N$-methyltransferase from rabbit skeletal muscle. Biochim. Biophys. Acta 923, 156-165.

Waelkens E., Gettemans J., De Corte V., De VILLE Y., GORIS J., VANDEKERCKHOVE J., MERLEVEDE W., 1995.' Microfilament dynamics:regulation of actin polymerization by actin-fragmin kinase and phosphatases. Adv. Enzyme Regul. 35, 199-227.

Wang J., Han X., Wong C. C., Cheng H., AslaNIAN A., XU T., LEAVIS P., RODER H., HEDSTROM L., YATES J. R. 3RD, KASHINA A. 2014. Arginyltransferase ATE1 catalyzes midchain arginylation of proteins at side chain carboxylates in vivo. Chem. Biol. 21, 331-337.

Wilson C., TERman J. R., GonzÁlez-Billault C., AHMED G., 2016. Actin filaments-A target for redox regulation. Cytoskeleton 73, 577-595.

Wong C. C., XU T., RaI R., BaIley A. O., YATES J. R. 3RD, WOLF Y. I., ZEBROSKI H., KASHINA A., 2007. Global analysis of posttranslational protein arginylation. PLoS Biol 5, e258.

ZHANG D., ZHANG D.-E., 2011. Interferon-Stimulated Gene 15 and the Protein ISGylation System. J. Interferon Cytokine Res. 31, 119-130.

Zhang F., SAHA S., Shabalina S. A., KaShina A. 2010. Differential arginylation of actin isoforms is regulated by coding sequence-dependent degradation. Science 329, 1534-1537.

ZhU J. X., Doyle H. A., Mamula M. J., Aswad D. W., 2006. Protein repair in the brain, proteomic analysis of endogenous substrates for protein L-isoaspartyl methyltransferase in mouse brain. J. Biol. Chem. 281, 33802-33813. 
KOSMOS Vol. $67,1,43-55,2018$

\author{
MARIA JOLANTA RĘDOWICZ
}

Laboratory of Molecular Basis of Cell Motility, Department of Biochemistry, Nencki Institute of Experimental Biology PAS,

3 Pasteur Str., 02-093 Warsaw, E-mail: j.redowicz@nencki.gov.pl

\title{
POSTTRANSLATIONAL MODIFICATIONS OF ACTIN
}

\section{Summary}

Actin, a constituent of the cytoskeleton of eukaryotic cells, is one of the most important as well as best evolutionary conserved proteins. This globular protein with molecular mass of $\sim 42.3 \mathrm{kDa}$ exists in the cell both in the monomeric and filamentous form, and ability to undergo dynamic reorganization of these two forms is absolutely crucial for cell survival. The monomer-filament transition, precisely controlled in time and space, is possible due to interaction of actin with a panoply of proteins binding to either monomeric or filamentous actin. Yet another factor is affecting actin organization, namely numerous posttranslational modifications. This review article is devoted to presentation of this broad and still unrecognized topic with emphasis on description of the type of actin modifications and how they affect actin structure and function.

Key words; actin, cytoskeleton, filament, regulation 